\title{
POST HERPETIC NEURALGIA AND OPHTAMOPLEGIA IN PATIENT WITH MULTIPLE SCLEROSIS : A CASE REPORT
}

\author{
Widodo Mardi Santoso ${ }^{1}$, Yeni Quinta Mondiani ${ }^{1}$, Machlusil Husna ${ }^{1}$, Rodhiyan Rachmatiar ${ }^{1}$ \\ ${ }^{I}$ Neurology Department, Medical Faculty, Brawijaya University, Saiful Anwar General Hospital, Malang, Indonesia. \\ Correspondence : widodoneuro@gmail.com
}

\begin{abstract}
Zoster Herpes which is also known as 'shingles' may cause infection on neuro system through the reactivation of the virus. This infection causes skin eruption along the affected dermatomal distribution and it is called post herpetics neuralgia. This condition occurs on approximately 9-15\% patients of zoster herpes who receive no treatment. Elderly women have a higher risk of the condition. Complete oftamoplegia is also related with zoster herpes. It was reported that there were 16 cases in the past one year with a relatively good prognosis (total recovery within 18 months) with an analysis starting from inflammation of trigeminus nervus to cavernosus sinus, cranialis nervus microinfark caused by vasculitis, meningeal inflammation, and demyelinisation (of autopsy). On the other hand, there are theories showing a correlation between zoster herpes infection and multiple sclerosis. Based on the epidemiologic study which has been conducted, that zoster herpes is influencing multiple sclerosis. This virus might induce autoimmune cascade and proinflammatory via particle like Toll - like receptor 4 (TLR-4).
\end{abstract}

Keyword : Herpes zoste, post herpetic neuralgia, ophtalmoplegia, multiple sclerosis

\section{PENDAHULUAN}

Virus zoster merupakan salah satu dari delapan virus herpes yang menginfeksi manusia. Virus ini termasuk dalam famili herpesviridae. Struktur virus terdiri dari sebuah icosahedral nucleocapsid yang dikelilingi oleh selubung lipid. Setelah infeksi primer, virus ini akan tetap berada di dalam akar saraf sensorik untuk hidup. Setelah reaktivasi, virus bermigrasi ke saraf sensoris pada kulit, menyebabkan ruam karakteristik dermatomal yang menyakitkan. Setelah resolusi, banyak individu mengalami nyeri pada distribusi dari ruam (postherpetic neuralgia) dengan lokasi terbanyak kedua pada nervus trigeminus $(1,2)$.

Herpes zoster menyebabkan perubahan saraf perifer oleh multiplikasi virus pada ganglion radiks dorsalis, dan migrasi cepat virus sepanjang akson saraf sensorik perifer menuju jaringan ikat kulit dan subkutan. Proses ini menimbulkan respon inflamatorik masif pada daerah yang terkena dan menyebabkan nyeri. Nyeri kemudian berlanjut melalui proses eksitasi dan sensitisasi berkelanjutan terhadap nosiseptor. Proses inflamatorik melibatkan kornu anterior dan posterior medulla spinalis, ditandai dengan kerusakan aksonal myelin yang meluas ke perifer dari, sehingga jumlah akhiran saraf di kulit yang dilayani neuron ini berkurang (3).

Herpes zoster oftalmica dapat menyebabkan oftamoplegi walaupun banyak faktor yang turut berkontribusi. Reaktivasi virus menyebabkan inflamasi dari akson yang mensuplai dermatom. Edgerton menyatakan bahwa inflamasi dari nervus trigeminus dapat secara cepat menyebar melalui sinus cavernosus untuk nantinya mempengaruhi nervus okulomotor. Nauman et al menyatakan, ditemukannya sel inflamasi kronik yang menunjukkan adanya vaskulitis oklusif $(4,5)$.

Prognosis kesembuhan sempurna setelah oftamoplegi komplit yang menyertai herpes zoster oftalmika adalah baik. Dalam salah satu review, dari 16 kasus, 9 di follow up, semua kasus menunjukkan perbaikan signifikan setelah 2 bulan dan perbaikan komplit dalam 18 bulan (6).

Kang et al menyebutkan studi epidemiologis tentang peran virus herpes zoster dalam perkembangan MS. Dikatakan bahwa beberapa virus herpes mencetusakan kaskade proinflamatori dan autoimun melalui partikel seperti Toll-like receptor 4 (TLR-4), dan faktor lingkungan infeksius yang berhubungan dengan MS juga masuk ke family herpesviridae. Dikatakan butuh waktu sekitar 100 hari untuk perkembangan dari infeksi herpes zoster, menuju timbulnya multiple sclerosis $(6,7)$.

\section{KASUS}

Pasien datang dengan keluhan nyeri, gatal dan panas pada wajah sebelah kanan kurang lebih 3 bulan sebelum kontrol ke poliklinik.

\section{Article History:}

Received: 9 Februari 2020; Accepted: 11 Februari 2020; Published: 1 Maret 2020

\section{Cite As:}

Santoso WM, Mondiani YQ, Husna M, Rachmatiar R. Post herpetic neuralgia and ophtamoplegia in patient with multiple sclerosis. Journal of Pain, Vertigo and Headache; 2020.1: 10-12. 
Nyeri yang dirasakan bersifat gatal, panas, seperti ditusuktusuk dan semakin memberat jika disentuh, cuaca panas, cuaca dingin dan terkena hembusan angin. Pasien sebelumnya menderita Herpes Zooster 3,5 bulan yang lalu tepat didaerah yang dirasakan nyeri oleh saat ini. 1,5 bulan yang lalu pasien mengeluh mata sebelah kanan menutup, kejadian mata sebelah yang menutup dirasakan tiba - tiba saat pasien bangun tidur.

Tidak ada keluhan mual maupun muntah. Tidak didapatkan kejang, keluhan bicara pelo, merot, kelemahan $1 / 2$ badan maupun kesemutan $1 / 2$ badan. Tidak ada gangguan BAK dan BAB. Tidak ada penurunan kesadaran, tidak ada keluhan demam, pandangan dobel, gangguan menelan, pusing berputar, batuk lama, keringat malam, keluar cairan telinga (-), penurunan berat badan.

Saat pasien dalam observasi di poli, 2 bulan kemudian pasien mengeluh mendadak lemah $1 / 2$ badan kiri saat bangun tidur. Dari pemeriksaan fisik didapatkan tensi 130/90, nadi 70x/menit, respirasi 20x/menit, suhu 36,80C. Pada pemeriksaan status neurologid didapatkan parese N. III total dan N. IV dekstra, hiperalgesia sesuai distribusi nervus V 1 dekstra dengan hemiparese sinistra yang didapatkan 2 bulan setelah pasien datang ke poli, tanpa didapatkan tanda rangsang meningeal, dengan reflek patologis babinski (+) pada ekstrimitas bawah kanan.

Dari pemeriksaan penunjang didapatkan darah lengkap dalam batas normal. Pada pemeriksaan radiologis, didapatkan foto thoraks juga dalam batas normal. Dari hasil pemeriksaan MRI dan MRV kepala didapatkan lesi multiple pons, periventrikel kanan kiri, lobus frontoparietal kanan kiri susp multiple sclerosis. Dan hasil MRI terbaru setelah pasien mendapat serangan hemiparese, lesi baru di korona radiate kanan, sugestif multiple sclerosis

Pada pasien diberikan gabapentin 1 x 300 mg untuk mengatasi nyeri neuropatiknya, dan dilakukan injeksi metilprednisolon dosis tinggi saat terdiagnosa multiple sclerosis. Saat ini keluhan pasien membaik, baik oftamopleginya (saat ini hanya didapatkan parese N III parsial, dan hemiparese kiri yang membaik).

\section{PEMBAHASAN}

Pada kasus ini dibahas seorang wanita usia 76 tahun datang dengan keluhan nyeri, gatal dan panas pada wajah sebelah kanan kurang lebih 3 bulan sebelum kontrol ke poliklinik. Diagnosis sebagai neuralgia pasca herpatika ditegakkan berdasarkan anamnesis, pemeriksaan fisik, dan pemeriksaan neurolgis.

Dari anamnesis diperolah bahwa pasien 3,5 bulan yang lalu pernah menderita penyakit herpes zooster dibagian daerah yang dirasakan nyeri saat ini. Setelah herpes zooster yang diderita sembuh dan meninggalkan bercak hipopigmentasi pada bagian tersebut, pasien mulai merasakan keluhan nyeri, gatal dan panas pada wajah sebelah kanan, semakin lama semakin berat terutama jika tersentuh, cuaca dingin, cuaca panas, dan hembusan angin. Pada pemeriksaan fisik sensorium compos mentis, tekanan darah 110/70 mmHg, suhu tubuh afebris. Pada pemeriksaan neurologis tidak dijumpai adanya rangsang meningeal maupun tanda peninggian TIK. Refleks fisiologis juga didapatkan normal. Didapatkan hiperalgesia pada distribusi cabang pertama nervus trigeminus. Maka diagnosis pada penderita ini dapat ditegakkan dengan Neuralgia Pasca Herpetika dan Post Herpes Zoster Oftalmika.

Secara umum herpes zoster menyebabkan perubahan saraf perifer oleh multiplikasi virus pada ganglion radiks dorsalis, dan migrasi cepat virus sepanjang akson saraf sensorik perifer menuju jaringan ikat kulit dan subkutan. Proses ini menimbulkan respon inflamatorik masif pada daerah yang terkena dan menyebabkan nyeri. Nyeri kemudian berlanjut melalui proses eksitasi dan sensitisasi berkelanjutan terhadap nosiseptor. Proses inflamatorik melibatkan kornu anterior dan posterior medulla spinalis, ditandai dengan kerusakan aksonal myelin yang meluas ke perifer, sehingga jumlah akhiran saraf di kulit yang dilayani neuron ini berkurang.

Pada pasien tidak diberikan terapi antiviral karena onset kedatangan pasien sudah $>2$ bulan. Dikatakan pasien telah mendapat obat salep dan obat minum (pasien tidak tahu nama obat). Pemberian acyclovir, famciclovir, atau valacyclovir berguna untuk menyembuhkan lesi kulit, mengurangi penyebaran virus, dan menurunkan resiko keterlibatan ocular. Beberapa laporan menyebutkan, famciclovir dan valacyclovir memberikan prognosa lebih baik dalam menyembuhkan nyeri pada herpes zoster dibanding acyclovir. Efektivitas steroid dan antiviral sendiri, atau kombinasi belum menjadi terapi pilihan pada herpes zoster, akibat minimnya mekanisme penyebab herpes zoster oftalmica $(8,9)$.

Lalu dari anamnesa, 1,5 bulan yang lalu pasien mengeluh mata sebelah kanan menutup, kejadian mata sebelah yang menutup dirasakan tiba - tiba saat pasien bangun tidur. Dari pemeriksaan fisik didapatkan oftamoplegia pada sisi kanan (sesuai lesi herpes zoster sebelumnya). Oftamoplegi dikatakan menjadi sequel dari herpes zoster oftalmica, dikatakan merupakan komplikasi yang late, yaitu sekitar 2 bulan setelah lesi herpes, dan muncul pada $11-29 \%$ pasien dengan herpes zoster oftalmika. Oftalmoplegia terjadi baik pada individu imunokompeten maupun imunokompromise.

Berbagai hipotesis telah disebutkan dalam menjelaskan mekanisme bagaimana herpes zoster oftalmica dapat menyebabkan oftamoplegi walaupun banyak faktor yang turut berkontribusi. Diketahui bahwa reaktivasi virus menyebabkan inflamasi dari akson yang mensuplai dermatom. Edgerton menyatakan bahwa inflamasi dari nervys trigeminus dapat secara cepat menyebar melalui sinus cavernosus untuk nantinya mempengaruhi nervus okulomotor. Sebagai tambahan. Nauman et al menyatakan, ditemukannya sel inflamasi kronik yang menunjukkan adanya vaskulitis oklusif $(4,5)$

Prognosis dari kesembuhan sempurna setelah oftamoplegi komplit yang menyertai herpes zoster oftalmika adalah baik. Dalam salah satu review, dari 16 kasus, 9 di follow up, semua kasus menunjukkan perbaikan signifikan setelah 2 bulan dan perbaikan komplit dalam 18 bulan (8). 2 bulan kemudian (bulan Oktober 2016) pasien mengeluh mendadak lemah $1 / 2$ badan kiri mendadak saat bangun tidur, disertai pelo dan merot. Dari pemeriksaan didapatkan keluhan hemiplegi S, parese NVII, XII S UMN type. Kriteria diagnosis MS menurut Mc Donald et al (2001) antara lain dua atau lebih serangan, bukti tanda klinis obyektif pada dua atau lebih lesi : Adanya bukti nyata terjadinya dua serangan 
yang tipikal pada multipel sklerosis yang didokumentasikan oleh bukti obyektif pada dua lesi dalam waktu yang berbeda dapat menegakkan diagnosis MS tanpa perlu pemeriksaan penunjang. Dari pemeriksaan penunjang yaitu MRI kepala didapatkan gambaran multiple sclerosis (8).

Dari riwayat sebelumnya, dimana pasien mengalami herpes zoster, dapat diambil benang merah diantara hubungan herpes zoster dengan kejadian multiple sclerosis. Kang et al menyebutkan studi epidemiologis tentang peran virus herpes zoster dalam perkembangan MS. Dikatakan bahwa beberapa virus herpes mencetusakan kaskade proinflamatori dan autoimun melalui partikel seperti Toll-like receptor 4 (TLR4), dan faktor lingkungan infeksius yang berhubungan dengan MS juga masuk ke family herpesviridae. DIkatakan butuh waktu sekitar 100 hari untuk perkembangan dari infeksi herpes zoster, menuju timbulnya multiple sclerosis.12 Dikatakan adanya DNA dari VZV pada sel MN pasien MS pada fase relaps, dan virus inii menghilang selama remisi (10).

\section{KESIMPULAN}

Telah dilaporkan kasus pasien wanita, 75 tahun dengan Post herpetic neuralgia, dengan ophtamoplegia yang akhirnya didiagnosis dengan multiple sclerosis. Neuralgia Pasca Herpetika (NPH) adalah suatu kondisi nyeri yang dirasakan di bagian tubuh yang pernah terserang infeksi herpes zooster. Herpes zooster sendiri merupakan suatu reaktivasi virus varicella yang berdiam didalam jaringan saraf.

NPH lebih banyak menyerang lansia dan orang dengan kekebalan tubuh yang rendah. Data seluruh dunia menunjukkan di antara pasien herpes zooster yang berumur di atas 60 tahun, 6\% masih merasakan nyeri saat 1 bulan sejak terkena herpes zooster, dan $1 \%$ masih merasakan nyeri 3 bulan sesudahnya.

Patofisiologi NPH terjadi oleh karena cedera neuron yang mengenai sistem saraf baik perifer maupun pusat. Cedera ini mengakibatkan neuron sentral dan perifer mengadakan discharge spontan sementara juga menurunkan ambang aktivasi untuk menghasilkan nyeri yang tidak sesuai pada stimulus yang tidak sesuai pada stimulus yang tidak menyebabkan nyeri. Biopsi kulit menunjukkan hilangnya ujung saraf bebas epidermal pada daerah yang terkena, namun, reinervasi tidak dibutuhkan untuk resolusi nyeri.

Selain neuralgia, herpes zoster dapat bermanifestasi sebagai oftamoplegia dengan beberapa dugaan mekanisme diantaranya gangguan pada sinus cavernosus. Dikatakan bahwa herpes zoster juga dapat menjadi pencetus munculnya multiple sclerosis pada pasien dengan keterlibatan reseptor diantaranya TLR-4 yang terlibat dalam proses infeksi.

\section{DAFTAR PUSTAKA}

1. Grinde B. Herpesviruses: latency and reactivation - viral strategies and host response. J Oral Microbiol. 2013 Jan;5(1):22766.

2. Feller L, Khammissa RAG, Fourie J, Bouckaert M, Lemmer J. Postherpetic Neuralgia and Trigeminal Neuralgia. Vol. 2017, Pain Research and Treatment. Hindawi Limited; 2017.
3. Devor M. Rethinking the causes of pain in herpes zoster and postherpetic neuralgia: The ectopic pacemaker hypothesis. Vol. 3, Pain Reports. Lippincott Williams and Wilkins; 2018.

4. Edgerton AE. Herpes Zoster Ophthalmicus: Report of Cases and a Review of the Literature. Trans Am Ophthalmol Soc [Internet]. 1942 [cited 2020 Feb 9];40:390-439. Available from: http://www.ncbi.nlm.nih.gov/pubmed/16693295

5. Naumann G, Donald J, Gass M, Font RL. Histopathology of Herpes Zoster Ophthalmicus. Am J Ophthalmol [Internet]. 1968;65(4):533-41. Available from: http://dx.doi.org/10.1016/0002-9394(68)93869-5

6. Corona T, Flores J. Herpes Zoster and Multiple Sclerosis. J Infect Dis [Internet]. 2011 Jul 15 [cited 2020 Feb 9];204(2):177-8. Available from: https://academic.oup.com/jid/articlelookup/doi/10.1093/infdis/jir243

7. Kang JH, Sheu JJ, Kao S, Lin HC. Increased risk of multiple sclerosis following herpes zoster: A nationwide, population-based study. J Infect Dis [Internet]. $2011 \mathrm{Jul}$ 15 [cited 2020 Feb 9];204(2):188-92. Available from: http://www.ncbi.nlm.nih.gov/pubmed/21653524

8. John AR, Canaday DH. Herpes Zoster in the Older Adult. Vol. 31, Infectious Disease Clinics of North America. W.B. Saunders; 2017. p. 811-26.

9. Gnann Jr. JW. Antiviral therapy of varicella-zoster virus infections [Internet]. Human Herpesviruses: Biology, Therapy, and Immunoprophylaxis. Cambridge University Press; 2007 [cited 2020 Feb 9]. Available from: http://www.ncbi.nlm.nih.gov/pubmed/21348091

10. Duarte LF, Farías MA, Álvarez DM, Bueno SM, Riedel CA, González PA. Herpes simplex virus type 1 infection of the central nervous system: Insights into proposed interrelationships with neurodegenerative disorders. Vol. 13, Frontiers in Cellular Neuroscience. Frontiers Media S.A.; 2019. p. 1-23. 